Report No. BMI-1457

UC-25 Metallurgy and Ceramics (TID-4500, 15th Ed.)

Contract No. W-7405-eng-92

\title{
CREEP AND CORROSION PROPERTIES OF
} ZIRCALOY-2 IN STEAM AT $750 \mathrm{~F}$

\section{by}

Edward J. Jablonowski

Frederic R. Shober

August 1, 1960

BATTELLE MEMORIAL INSTITUTE 505 King Avenue

Columbus 1, Ohio 


\section{DISCLAIMER}

This report was prepared as an account of work sponsored by an agency of the United States Government. Neither the United States Government nor any agency Thereof, nor any of their employees, makes any warranty, express or implied, or assumes any legal liability or responsibility for the accuracy, completeness, or usefulness of any information, apparatus, product, or process disclosed, or represents that its use would not infringe privately owned rights. Reference herein to any specific commercial product, process, or service by trade name, trademark, manufacturer, or otherwise does not necessarily constitute or imply its endorsement, recommendation, or favoring by the United States Government or any agency thereof. The views and opinions of authors expressed herein do not necessarily state or reflect those of the United States Government or any agency thereof. 


\section{DISCLAIMER}

Portions of this document may be illegible in electronic image products. Images are produced from the best available original document. 
TABLE OF CONTENTS

$\underline{\text { Page }}$

ABSTRACT . . . . . . . . . . . . . . . . . . . . . . 1

INTRODUCTION

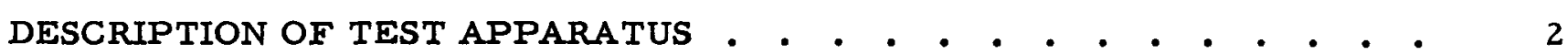

DESCRIPTION OF TEST SPECIMENS AND TEST PROCEDURE . • • • • • • 11

EXPERIMENTATION AND RESULTS

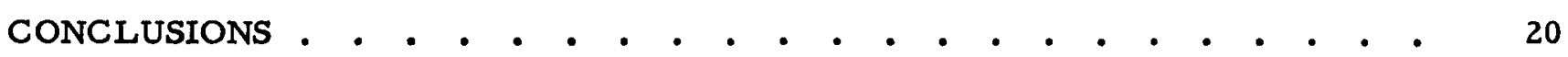

REFERENCES • • • • • • • • • • • • • • • • • • • • . • 20 


\title{
CREEP AND CORROSION PROPERTIES OF ZIRCALOY-2 IN STEAM AT $750 \mathrm{~F}$
}

Edward J. Jablonowski and Frederic R. Shober

\begin{abstract}
Test equipment to determine the creep properties of Zircaloy-2 in a 750 F 500-psi steam atmosphere was designed and constructed. Duplicate tests were performed at stresses to produce failure in approximately 1,10,100, and $1000 \mathrm{hr}$. A comparison between these data and data obtained in vacuum-test equipment shows that a corrosive test atmosphere does not alter ductility or failure times appreciably.
\end{abstract}

\section{INTRODUCTION}

Zircaloy- 2 is used extensively as a cladding material for nuclear fuels subjected to pressurized-water environments because of its excellent corrosion resistance, its creep strength at medium temperatures $(500$ to $750 \mathrm{~F}$ ), and its low neutron-capture cross section. It is capable of protecting the more reactive fuel materials against the corrosive action of elevated-temperature water and can provide some restraint for a dimensionally unstable fuel material.

While data concerning the strength and corrosion resistance of Zircaloy are readily available, little is known about the effects on this material of a combination of stress and corrosion. It is known that hydrogen as a corrosion product of zirconium and zirconium alloys can, under favorable conditions, form $\mathrm{ZrH}$. Zirconium hydride present as a second phase in a fuel-element cladding or structural component could cause severe embrittlement.

The investigation reported here was concerned with the determination of the effect of corrosion in a pressurized steam atmosphere on the creep properties of Zircaloy-2. It was believed that such experiments would not only provide a means of measuring ductility by creep, but would also provide a measure of the creep strength of Zircaloy-2 in a corrosive medium.

Because equipment to perform creep tests under these conditions is unavailable from commercial sources, the major effort in the program centered on the design and assembly of suitable apparatus. When this phase of the investigation was completed, tests at several stress levels were initiated to secure preliminary data on the creep behavior of Zircaloy-2 in 750 F 500-psi steam. Data from a concurrent program concerned with the creep of Zircaloy-2 at $750 \mathrm{~F}$ in vacuum were employed in evaluating the results. 
The test units consisted of five components: a pressure vessel, external heaters, load assembly, extensometer, and specimen grip adapters. A major problem of design was finding a suitable technique to maintain a sealed pressure vessel while applying a load through the load assembly. There appeared to be two comparatively simple ways to do this: (I) by effecting a seal to the pressure vessel with a metal bellows, and (2) by placing a rubber gasket-type seal around the load rod at the exit port of the pressure vessel. Although both methods required calibration of the load transmitted to the specimen, the second technique did not require changes of load compensation during test. Load compensation would be necessary for any load applied through a bellows to adjust for the relatively large spring constant of a bellows suitable for use with 500 psi steam. The bellows technique also would have required that a considerably more sensitive pressure controller be used in conjunction with the pressure vessel to maintain constant internal pressure. A variable portion of the test load would have resulted from the influence of the variable internal pressure on the bellows. It appeared that a more accurate and more constant load could be applied through a load rod and seal with less opportunity for mechanical failure.

Three pressure vessels manufactured by Autoclave Engineers, Inc., from AISI Type 316 stainless steel were employed in the program. These autoclaves are approximately 25 in. long with a 1-1/2-in. ID and a wall thickness of 9/16 in., and were constructed and tested to withstand $3000 \mathrm{psi}$ at $750 \mathrm{~F}$. They have removable heads at each end to facilitate insertion of test specimens. The top head contains a gas inlet, two holes to accommodate thermocouples, and a rupture diaphragm for relief of excess internal pressure. The bottom cover plate has one 5/8-in. port for the load rod and two smaller holes for the extensometer rods. A metal gasket at the top and a rubber gasket at the bottom between the cover plate and the body of the autoclave seal the system to maintain internal pressure.

The autoclaves were mounted in individual cubicles constructed of Flexangle frame, and were placed at a sufficient height to allow space for the lever-arm assembly and extensometer instrumentation. Figure 1 shows one such unit with the lever arm in place. A schematic drawing of the pressure chamber and creep-test-unit components is shown in Figure 2 .

The test specimens were fastened to a top adapter which was fixed at the top through a threaded rod. Axial alignment of the test specimen was obtained by an arrangement of pin connections such that they were movable in two directions, $90 \mathrm{deg}$ to one another, in planes perpendicular to the cross-sectional plane of the autoclave. The specimen was pinned at the grip end between two serrated side plates and held firmly in place with a machine bolt and nut. The load rod was attached to the bottom of the specimen through a similar arrangement. The load rod is tubular to allow for an extensometer rod to be attached inside. Starting with the top cover plate and proceeding downward vertically along the center of the autoclave, these are a connector to the top plate, adapters movable in two directions to aid axial loading, the sheet-type specimen, bottom adapters from specimen to load rod, and the load rod, which extends through the bottom plate. 


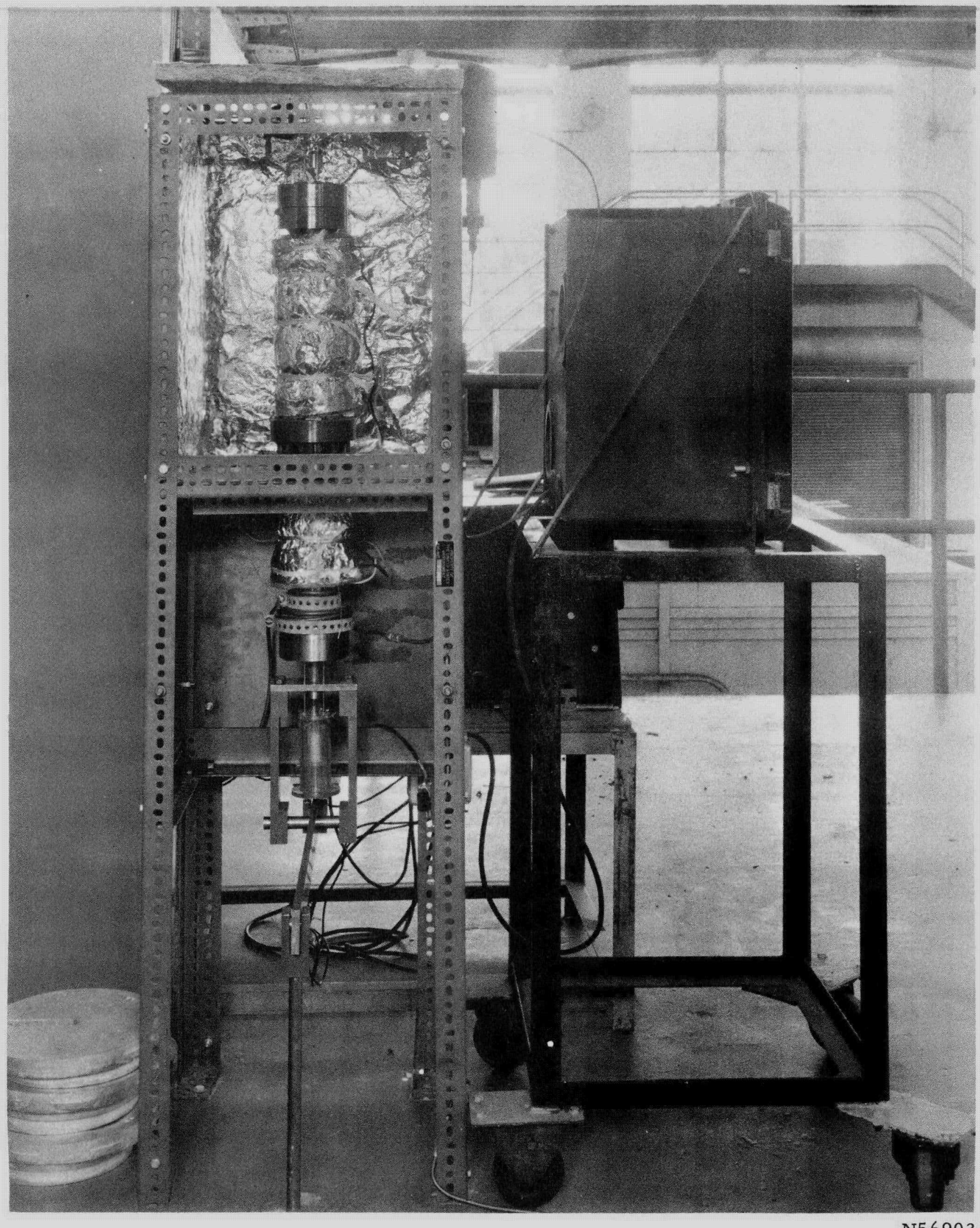

FIGURE 1. TEST UNIT SHOWING STAND, AUTOCLAVE, LVDT ATTACHMENT AND LEVER-ARM ASSEMBLY 


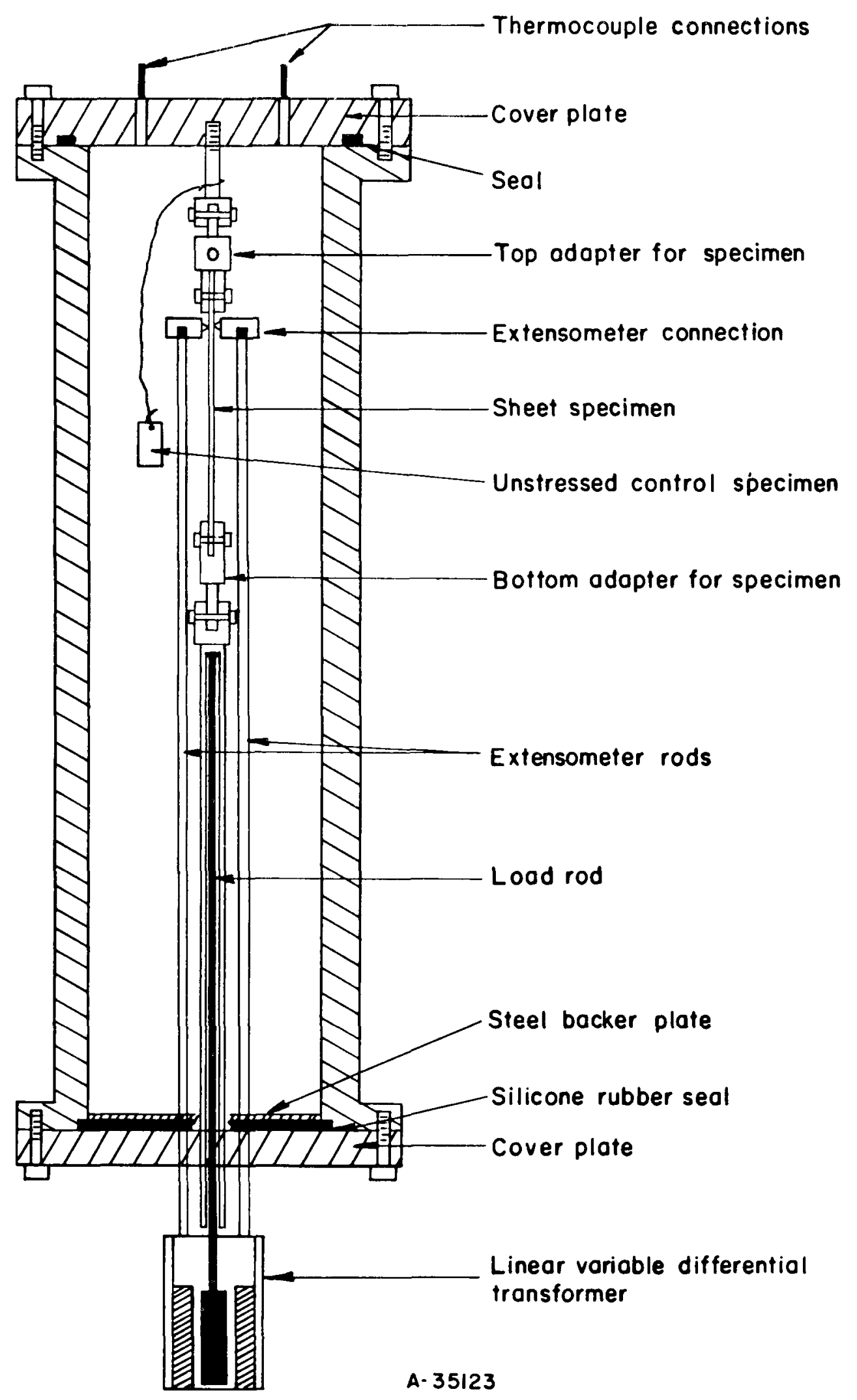

FIGURE 2. SCHEMATIC OF PRESSURE CHAMBER AND CREEP-UNIT COMPONENTS 
The load rod was attached, through a yoke arrangerini., 10 s lorer arm which had a 9-to-1 ratio. The yoke arrangement permitted the artachment of an extensometer activated by the relative movement of rods attached mechanically to the specimen at the top of its gage section and a rod connected to the bottom specimen adapter through the tubular portion of the load rod. By attaching the extensometer to a rod connected in this manner, the deformation occurring in the load rod is not measured.

An LVDT (linear variable differential transformer) was used to measure the creep deformation. For this work, the LVDT was mounted within a Lucite case such that the coils could be moved vertically by a manual adjustment. The manual adjustment provided a means to increase the range of the recorder. The extensometer rods connected to the top of the specimen were fixed to the case containing the coils, and the core was fixed to the rod running through the tubular load rod leading from below the bottom specimen adapter.

A seal was required between the main portion of the autoclave and the bottom cover plate, which contained holes to accommodate the extensometer rods and the load rod, to retain a pressurized system during test. A silicone-rubler seal, which fitted over the rods extending out of the autoclave, was placed between the cover plate and a stainless steel backer plate. Either an external or an internal pressure caused a slight extrusion of the seal around the rods and against the metal plates, effecting an adequate seal. The frictional forces produced by such an extrusion action were a minimum for the seal material selected.

The heaters used in these test units were individual rectangular-shaped stainless steel-covered units. The resistance wire within each unit was Chromel A. Ten units were wired in series and placed side by side around the circumference of the autoclave at two levels. The top-level heaters maintained specimen temperature, and the lower level heaters maintained water at elevated temperatures to produce steam under pressure for the test atmosphere. The control of these temperatures was achieved by placing Chromel-Alumel thermocouples on the wall of the autoclave adjacent to the heaters. Steam pressures up to approximately $3000 \mathrm{psi}$ can be produced in a closed system in this manner.

Tubular copper coil was formed around the lower portion of the pressure vessel in the vicinity of the rubber gasket. Cold water was flowed through the coil to maintain the lower portion of the test vessel at a low enough temperature to prevent deterioration of the gasket by heat. A water flow of approximately $1 / 2 \mathrm{gpm}$ was necessary to maintain a sufficiently low temperature. The bottom-cover-plate temperature was kept below room temperature during the test.

Auxiliary measuring and controlling systems used in conjunction with the test apparatus were placed as shown in Figure 3. Tha external pressure system was designed for two purposes: (1) to measire the internal pressure during the test, and (2) to provide a means of determining the operational characteristics of the test apparatus under simulated pressure conditions without temperature. For these purposes, a rather simplified system was designed which included a supply of gas (compressed air), a series of valves, and a pressure-indicating gage. A Bourdon pressure gage with a range from 0 to $1500 \mathrm{psi}$, one full division equaling $10 \mathrm{psi}$, was used to measure the pressure of the system. It could be read directly to one-half of a division and estimated to one-fourth of a division. The sensitivity of the indicating gage provided a means to 


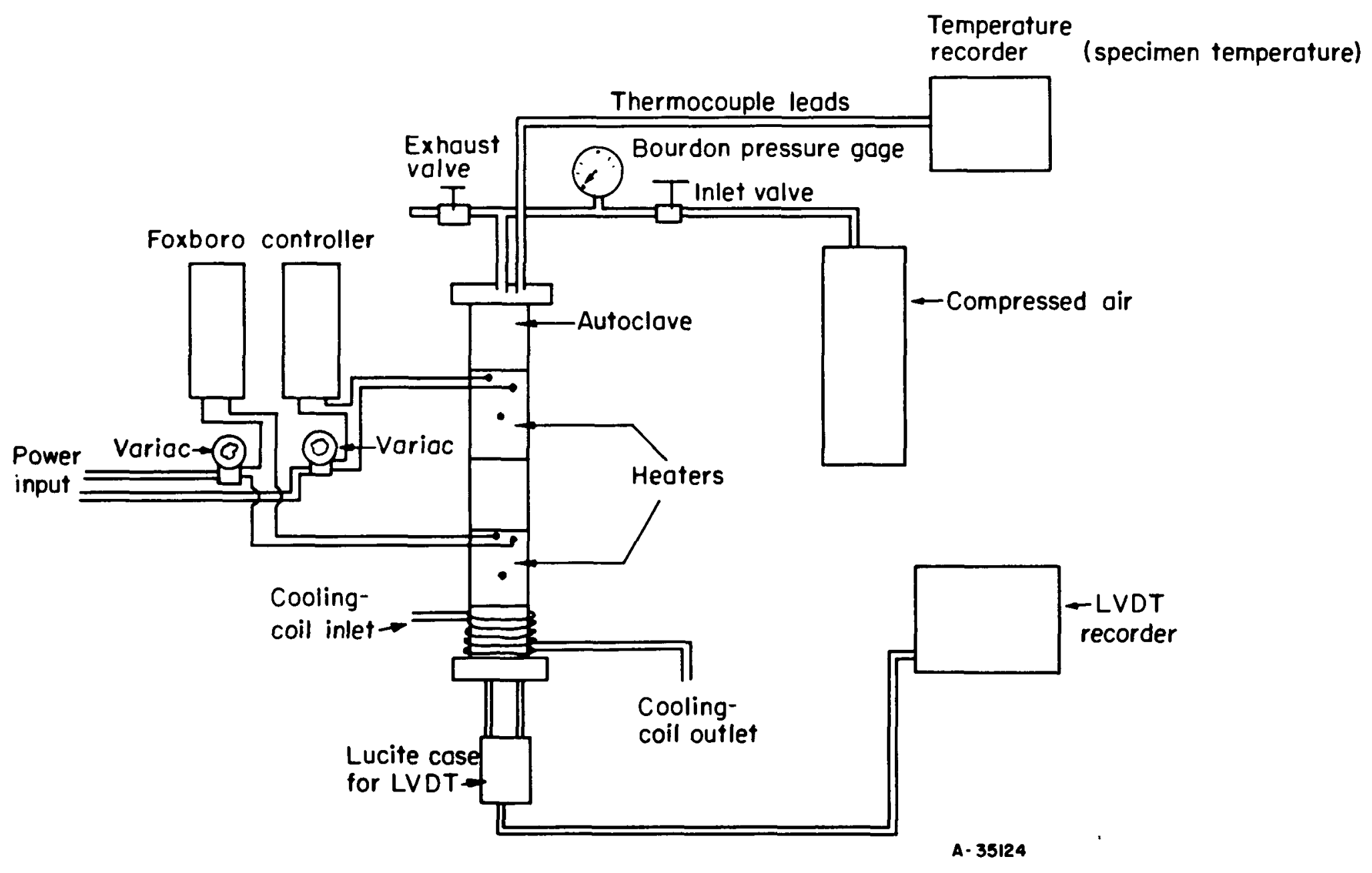

FIGURE 3. SCHEMATIC OF TEST UNIT AND AUXILIARY CONTROL COMPONENTS 
measure stress fluctuations on the specimen to \pm 50 psi. The effects of various pressures between atmospheric and $1500 \mathrm{psi}$ on the frictional forces between the rubber gasket and the load rod were determined.

Because of frictional forces imposed on the load rod, calibration prior to testing was necessary to determine lever-arm ratio, load on specimen under test conditions, portion of load produced by steam pressure, absolute extensometer movements, and the temperature gradient along the longitudinal axis of the test specimen under test conditions. A load cell was used in place of a test specimen for the load-calibration tests. It consisted of a stainless steel sheet specimen with Type A-7, SR-4 strain gages mounted on each side. The load cell was calibrated, and a load-versusdeformation curve within the elastic range of the sheet specimen was prepared. From this plot, a direct relation of extension, in microinches, as indicated by SR-4 strain gages, could be obtained with the load applied. The validity of the calibration curve was based on the elastic modulus of the load-cell material, as determined by the stressversus-strain curve.

The pressure component of the load was determined by pressurizing the unit from atmospheric pressure to 500 psi in 100-psi increments and noting the corresponding load, as determined from the SR-4 readings of the load cell. Some time lapse for equilibrium conditions was apparently related to the action of the rubber seal extruding down around the load rod. Figure 4 shows the load-versus-pressure curve for the three test units. Test Unit 3 exhibited a greater frictional force between load and seal at the higher internal pressure, as indicated by the change of slope of the curve.

In order that the frictional force between the rubber seal and the load rod could be determined, the calibration procedure was to load and unload $40 \mathrm{lb}$ through the lever arm in approximately 5-1b increments in the following order: (1) without the bottom cover plate, (2) with the bottom cover plate but without the rubber gasket, (3) with the bottom cover plate and the rubber gasket but without internal test pressure, and (4) with the bottom cover plate, with the rubber gasket, and with internal pressure equal to test conditions. Each step was done in duplicate. The load applied through the lever arm was plotted versus the load indicated by the load cell for each condition. The lever-arm ratio could be determined, and changes in ratio reflected the effect of the frictional force of the gasket on the load rod. Under the same conditions, deflection of the extensometer was recorded for each increment of load. Upon reduction of these values to strain per inch, they could be compared directly with changes in SR-4 readings of the load cell.

The results of these calibrations are shown in Figures 5 and 6 . The differences that can be observed in the curves are apparently the result of frictional forces between the rubber gasket and the metal rods. These data were employed to make the corrections in test load that were necessary to obtain a desired test stress on the specimen.

The thermal gradient along the test specimen was determined under test conditions. The thermal gradient was found to be similar in all test units and a test temperature of $750 \pm 5 \mathrm{~F}$ was maintained easily. Temperatures at the center of the specimen were about $5 \mathrm{~F}$ lower than positions $3 / 4 \mathrm{in}$. away from it in either direction. This gradient, no doubt, resulted from a large heat sink, at either end of the test specimen; however, these values fell well within the range of test-temperature tolerances specified for test conditions. 


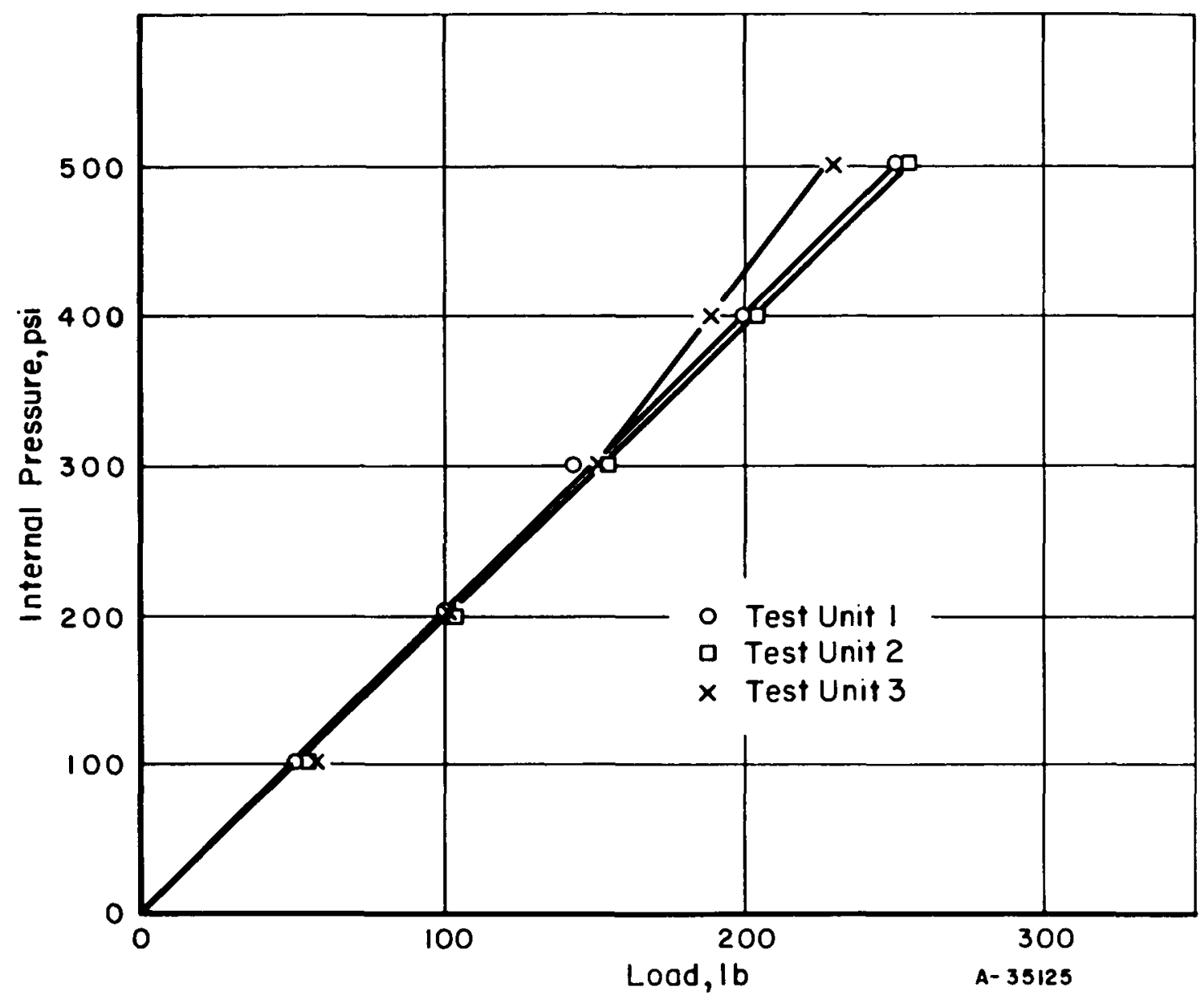

FIGURE 4. INTERNAL PRESSURE VERSUS LOAD ON LOAD ROD FOR TEST UNITS 1, 2, AND 3 


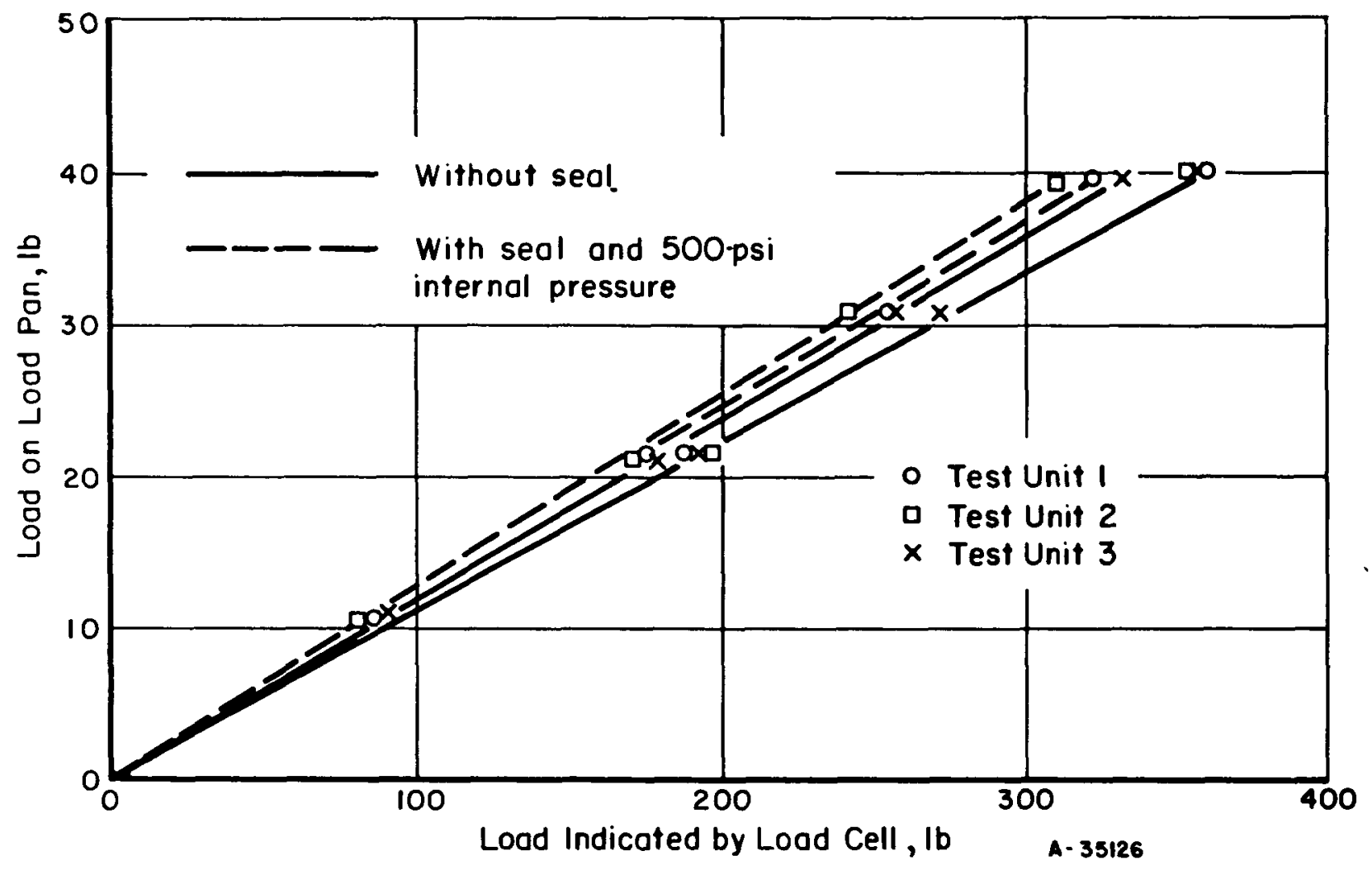

FIGURE 5. LOAD ON LEVER - ARM PAN VERSUS INDICATED LOAD SHOWING CHANGE OF EFFECTIVE LEVER-ARM RATIO BY FRICTIONAL FORCE OF RUBBER GASKET 


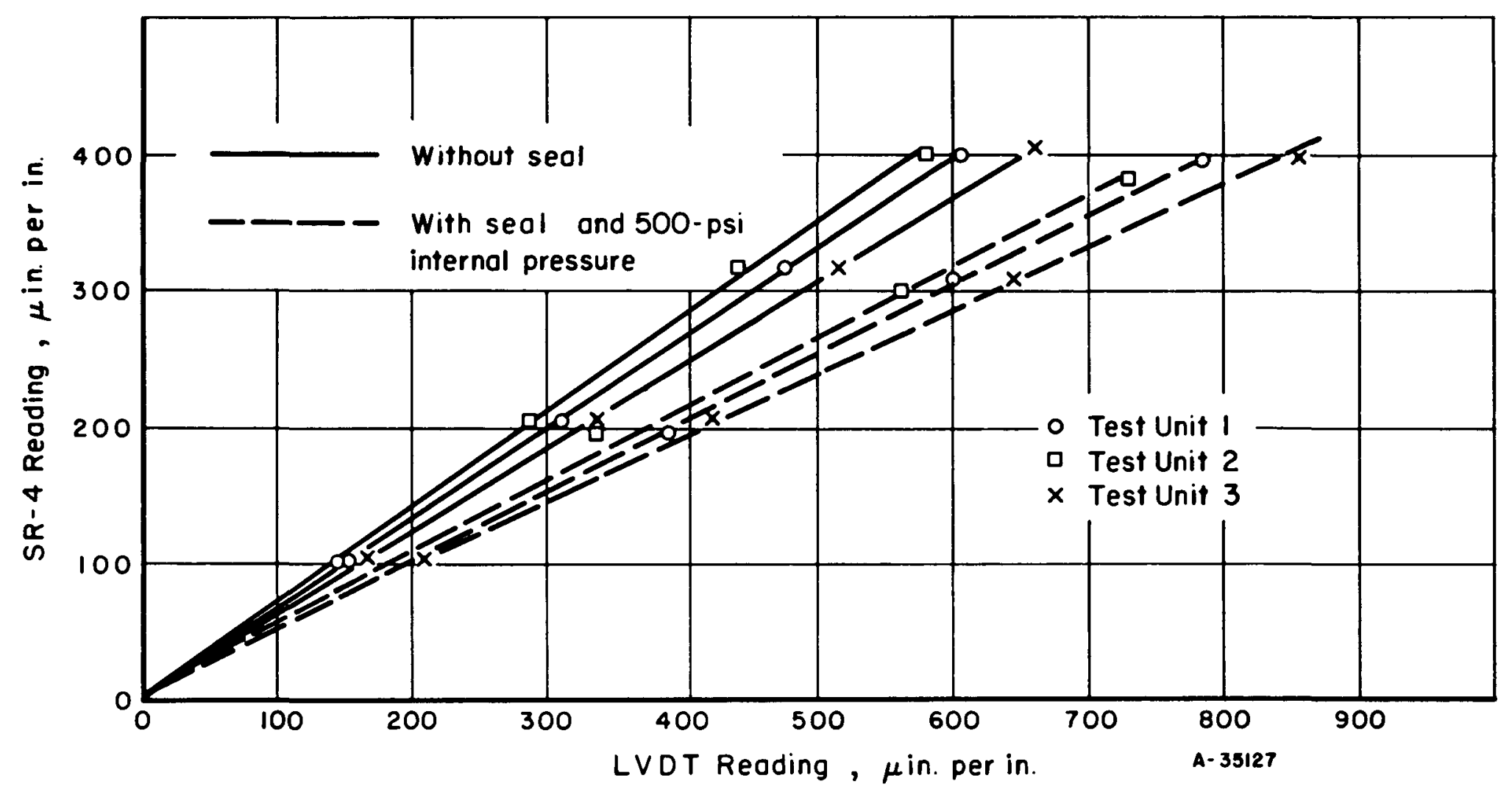

FIGURE 6. CALIBRATION CURVES FOR EXTENSOMETER, LOAD-CELL EXTENSION VERSUS EXTENSOMETER EXTENSION 
DESCRIPTION OF TEST SPECIMENS AND TEST PROCEDURE

The Zircaloy- 2 used in this investigation was provided by the General Electric Knolls Atomic Power Laboratory in the form of 3/8-in.-thick plate. The material was reported by KAPL to have the following fabrication history:

Cold rolled 25 per cent to a final $3 / 8-$ in. thickness

Annealed at $750 \mathrm{C}$ for $1 / 2 \mathrm{hr}$ in vacuum and furnace cooled

Pickled to remove 0.002 in. of material

Annealed at $600 \mathrm{C}$ for $1 / 2 \mathrm{hr}$ in vacuum and furnace cooled.

Results from preliminary tests at $28,500 \mathrm{psi}$ in $750 \mathrm{~F}$ steam showed that deformations of 2.3 and 3.0 per cent extension were obtained in 2.5 and $66 \mathrm{hr}$, respectively. These deformations were indicative of cold-worked material rather than annealed. The Rockwell B hardness was determined as $96 \mathrm{R}_{\mathrm{B}}$. Previous work at Battelle on the creep properties of cold-worked Zircaloy- 2 had shown that 15 per cent cold-worked material had similar hardnesses. Knolls also verified that $96 R_{B}$ is common to 15 per cent coldworked material. Several creep specimens were then annealed at $775 \mathrm{C}$ for $1 / 2 \mathrm{hr}$ in vacuum and furnace cooled. The resulting hardnesses were $89 \mathrm{R}_{\mathrm{B}}$. Tensile properties of this annealed material were not determined at room or elevated temperatures.

The as-received plate was split in the plane of rolling and creep specimens were milled to the specification shown in Figure 7. Corrosion blanks $7 / 8$ by 2 by $1 / 16$ in. were also machined from the as-received stock. The surfaces of the creep specimens were not ground and, consequently, had a finely corrugated appearance. The samples were then annealed for $1 / 2 \mathrm{hr}$ at $775 \mathrm{C}$ in a vacuum furnace with a pressure of 0.0003 $\mathrm{mm}$ of mercury and furnace cooled. The annealed specimens were pickled in a solution of 39 volume per cent $\mathrm{HNO}_{3}-3.8$ volume per cent $\mathrm{HF}-57.2$ volume per cent $\mathrm{H}_{2} \mathrm{O}$, which reduced the roughness of the machine finish. Approximately 0.001 in. of material was removed from all surfaces by pickling. The specimens were washed thoroughly following pickling, after which time they were handled exclusively with white cotton gloves. Dimensions were measured and weights were obtained on an analytical balance on both the creep and the corrosion specimens prior to testing.

In preparation for test, the specimens were placed in the top and bottom grips and suspended in a vertical position. The upper grip was threaded into the top cover plate. The weight of the load-rod assembly tended to axially align the test specimen while the upper and lower specimen-grip sections were pinned. The extensometer was mounted on the specimen, and a thermocouple was positioned through the top cover plate so that the beaded end was touching the center of the gage section. This thermocouple was used to record specimen temperature during test The corrosion specimen was then suspended by a stainless steel wire at a level comparable with that of the gage section of the creep specimen. The grip specimen and load-rod assembly were placed in the autoclave by lowering through the top opening. Top and bottom cover plates were bolted in place with gaskets. The system was pressurized with air to seat the rubber gasket around the load rod and extensometer rods. The case containing the LVDT was attached to the extensometer rods and the lever-arm assembly was connected to the load rod. All attachments were made to recorders and controllers, and the bottom of the autoclave was filled with water. The specimen was brought to test temperature $(750 \mathrm{~F})$ and a 500-psi pressure for about $1 \mathrm{hr}$ prior to loading. Then the appropriate load was 


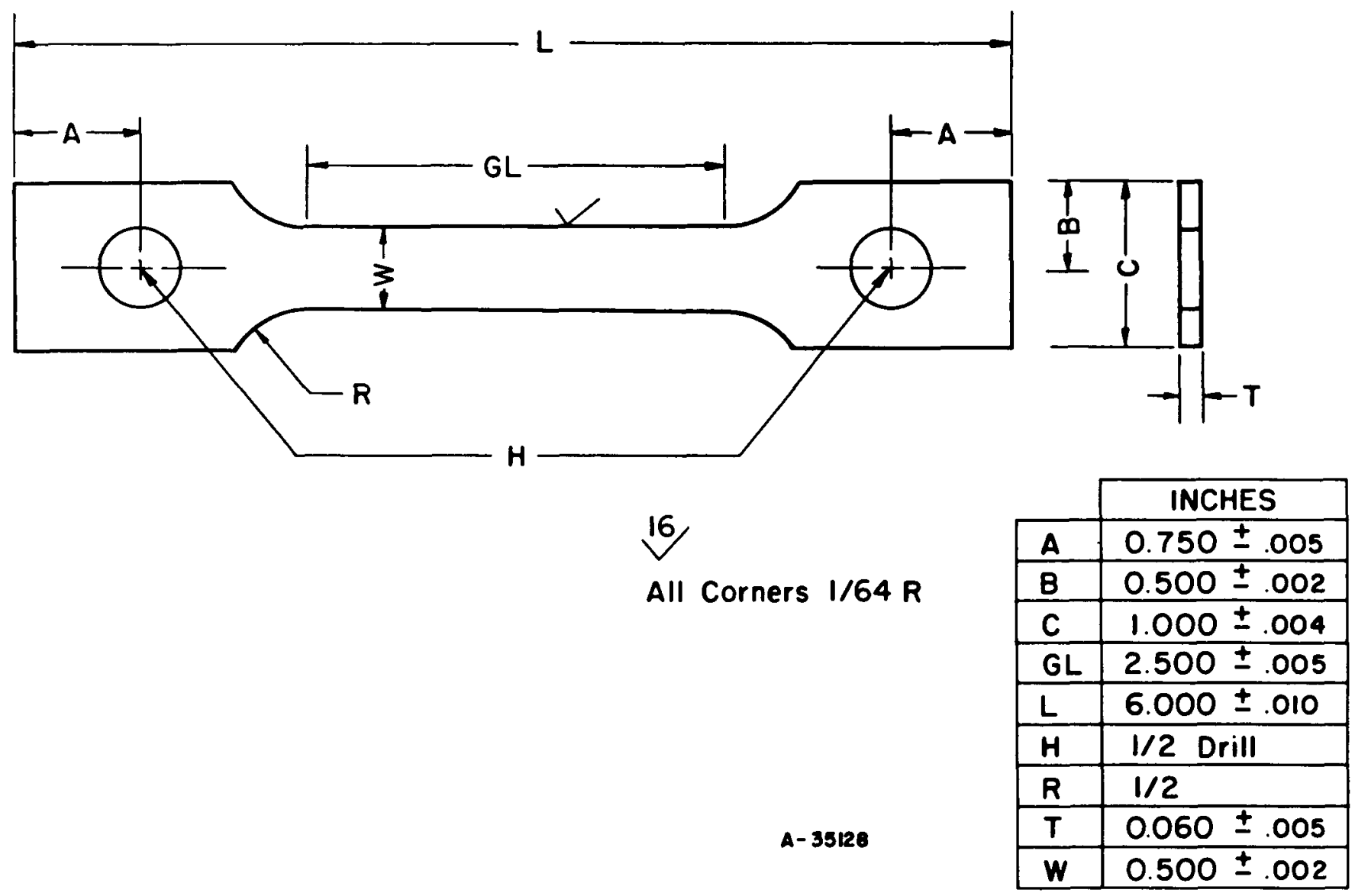

FIGURE 7. CREEP-TEST SPECIMEN 
placed on the load pan of the lever arm, and the deformation was recorded. Sufficient deformation readings were taken to define a time-versus-deformation curve for all tests. The tests were continued to rupture or, in one case, to approximately $1200 \mathrm{hr}$. Upon completion of the tests, both the creep and corrosion specimens were removed with care and were reweighed on an analytical balance to determine weight changes resulting from corrosion during test.

\section{EXPERIMENTATION AND RESULTS}

Upon completion of the design and the construction of the special equipment discussed in the previous sections, the test program was initiated. A series of tests was performed in $750 \mathrm{~F}$ steam at $500 \mathrm{psi}$. Data from these tests were compared with $750 \mathrm{~F}$ creep data from tests performed in vacuum for another program. Thus, information could be obtained about the effect of the steam atmosphere on the creep properties, and the role played in this effect by contamination which results from exposure to the test atmosphere. The most likely contaminants in this system are hydrogen and oxygen.

During corrosion of zirconium by water or steam, a relatively small fraction of the hydrogen released during corrosion will diffuse through the oxide layer and enter the metal. Hydrogen diffuses through zirconium rapidly at $750 \mathrm{~F}$, the testing temperature, so there is a question whether the increased hydrogen contents, $50 \mathrm{ppm}$, in the bulk of the material, might significantly affect the creep-rupture properties.

Such amounts of hydrogen do have an effect on the low-temperature notched-bar impact properties of zirconium (1), but do not affect the tensile properties, or the notched-bar impact properties, at elevated temperatures. It also seems unlikely that the hydrogen would have a significant effect on creep-rupture properties.

However, hydrogen might have a significant effect on creep-rupture properties in a service application, for the reason that under a thermal(2) or stress gradient(3), hydrogen can migrate to produce high local concentrations, up to several hundred ppm, of hydrogen.

Contamination by oxygen may also have an effect. At testing temperatures, oxygen diffusion is too slow for there to be any significant increase in oxygen concentration in the body of the material, so that any effects would of necessity result from effects of the oxide surface layer on the creep properties of zirconium.

The oxide films are quite thin, a small fraction of a per cent of the total specimen thickness, so any strengthening effect of the film itself seems unlikely. Thus, the only effect which might be expected would result from the effect of the film on the flow of dislocations. Such effects would not be expected to be sensitive to the thickness of the oxide layer, just to its presence or absence.

(1) References at end. 
Since this is the case, no effects of oxygen contamination were expected to be observable in this work. Any effects would be apparent only if the results could be compared with results from tests of specimens free of oxide films. No such data are available, and none could be obtained in this study, since, even for those tests made in vacuum, there was still filming of the material because the ultrahigh vacuum necessary to prevent significant filming of the Zircaloy could not be achieved. The surfaces of specimens tested in vacuum showed a golden to blue tarnish. Weight-gain data were not available from these tests. Thus, no effects of surface-oxide contamination were expected to be observable, with one possible exception: if the oxide films crack during deformation, the cracks in the oxide layer act as notches.

Ten tests were performed in steam at stresses calculated to produce failure within approximately $1,100,500$, and $1000 \mathrm{hr}$. Duplicate tests were run at five stress levels, and the results were compared with results from three tests conducted in vacuum. These results are given in Table 1. A comparison of the creep data is shown by a set of design curves in Figure 8 . The rupture times and the total elongations at rupture are shown for both the tests conducted in steam and those in vacuum. Figures 9, 10, and 11 show the deformation-versus-time curves for both test conditions. The data plotted for the vacuum tests are not from duplicate test specimens, and, hence, do not show the normal spread of creep data.

There was fair agreement between the rupture times and the total elongations obtained in steam with those obtained from tests in vacuum. There are two apparent irregularities in the elongations: (1) the elongation at rupture for the test in vacuum at 21,800 psi is 21.3 per cent, as compared with approximately 30 per cent for tests at comparable stresses in steam, and (2) at a lower stress of 17,500 psi in vacuum the elongation at rupture was 45.7 per cent. It is thought that the lower elongation might have resulted from testing irregularities and could be resolved with more tests. Although the stress dependency of the elongation at rupture is such that greater total elongations can be expected from lower stresses and longer rupture times, 45.7 per cent appears to be high for Zircaloy-2. However, it does compare quite well with the elongation obtained in another test conducted in vacuum in which the specimen failed in approximately $3600 \mathrm{hr}$.

If one looks at the 2 and 5 per cent deformation curves (the stress-versus-time relation for 2 and 5 per cent total deformation) obtained from steam-test data and for vacuum-test data, it appears that the more corrosive atmosphere might tend to increase the creep resistance of Zircaloy- 2 at the lower stresses. Since there are few data in this stress range; the results are inconclusive. The shape of the deformationversus-time curves appears quite regular. The data obtained from steam-atmosphere tests do, however, show a more distinct primary stage of creep than do the curves from vacuum-test data. This could result from the combination of strain hardening in the earlier stage of creep with the formation of the oxide layer.

Examination of the oxide layer formed on the creep and corrosion specimens during test revealed a black adherent oxide which had only a very slight tendency to spall. Table 2 lists the weight gains for both the corrosion and creep specimens after test. The specimens from one creep and one corrosion test showed a weight loss. This weight loss cannot be explained since all other specimens showed a weight gain after test. There appears to be no correlation of weight-gain data with time at test or with test conditions. 


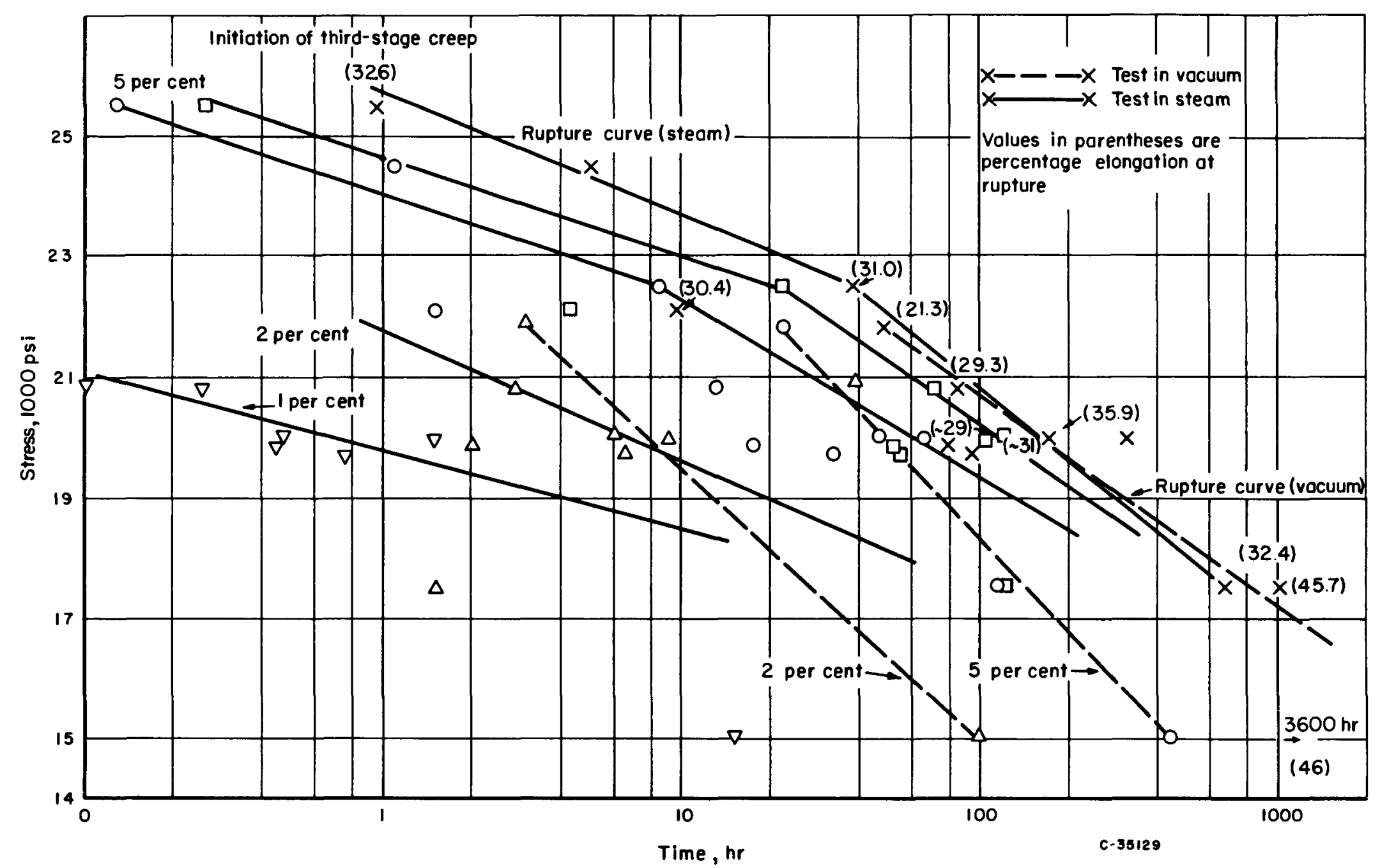

FIGURE 8. DESIGN CREEP CURVES SHOWING A COMPARISON BETWEEN RUPTURE TIMES IN VACUUM AND 750 F STEAM FOR ZIRCALOY -2 


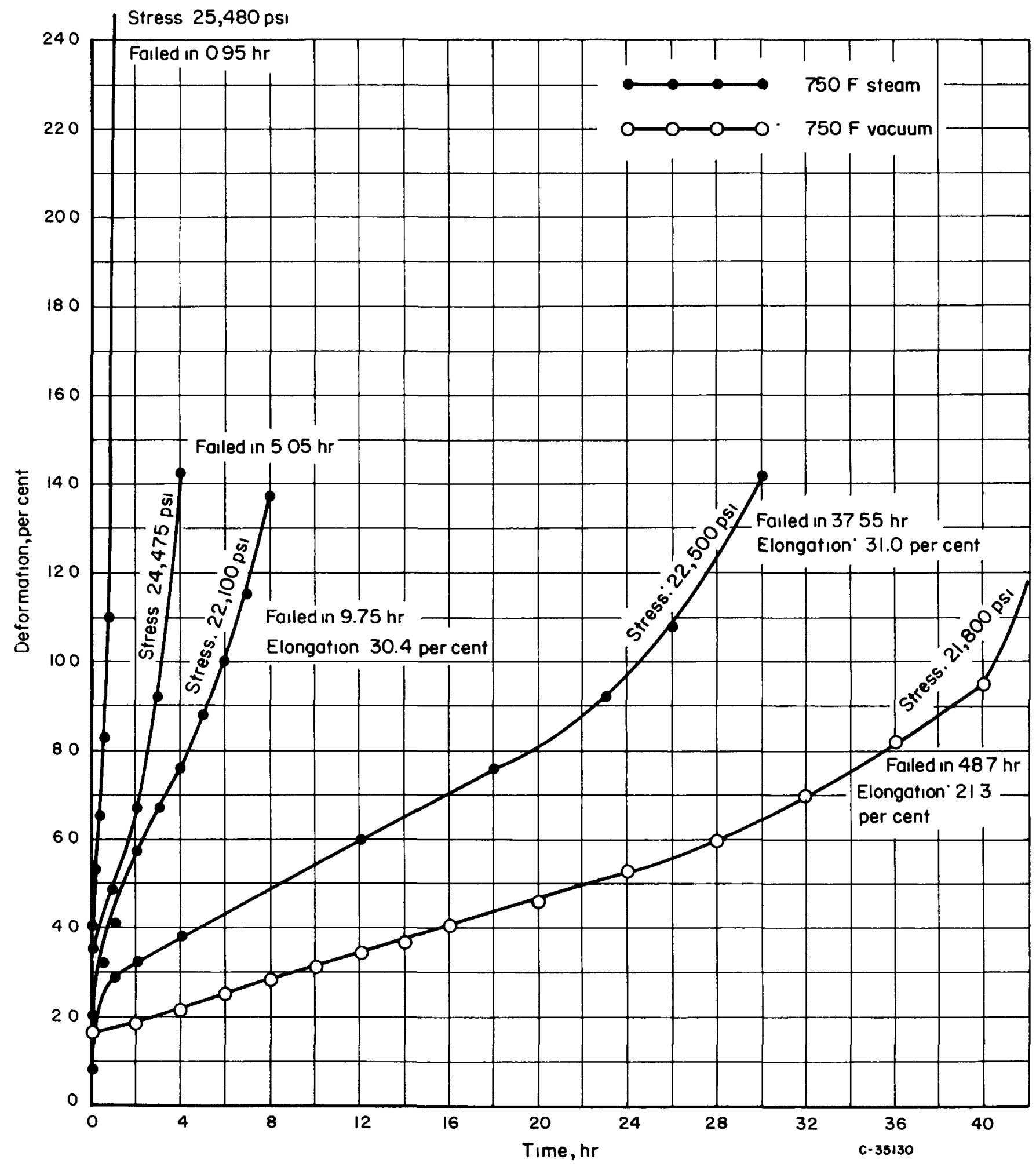

FIGURE 9. DEFORMATION-VERSUS-TIME CURVES FOR ZIRCALOY-2 TESTED IN 750 F STEAM AND VACUUM 


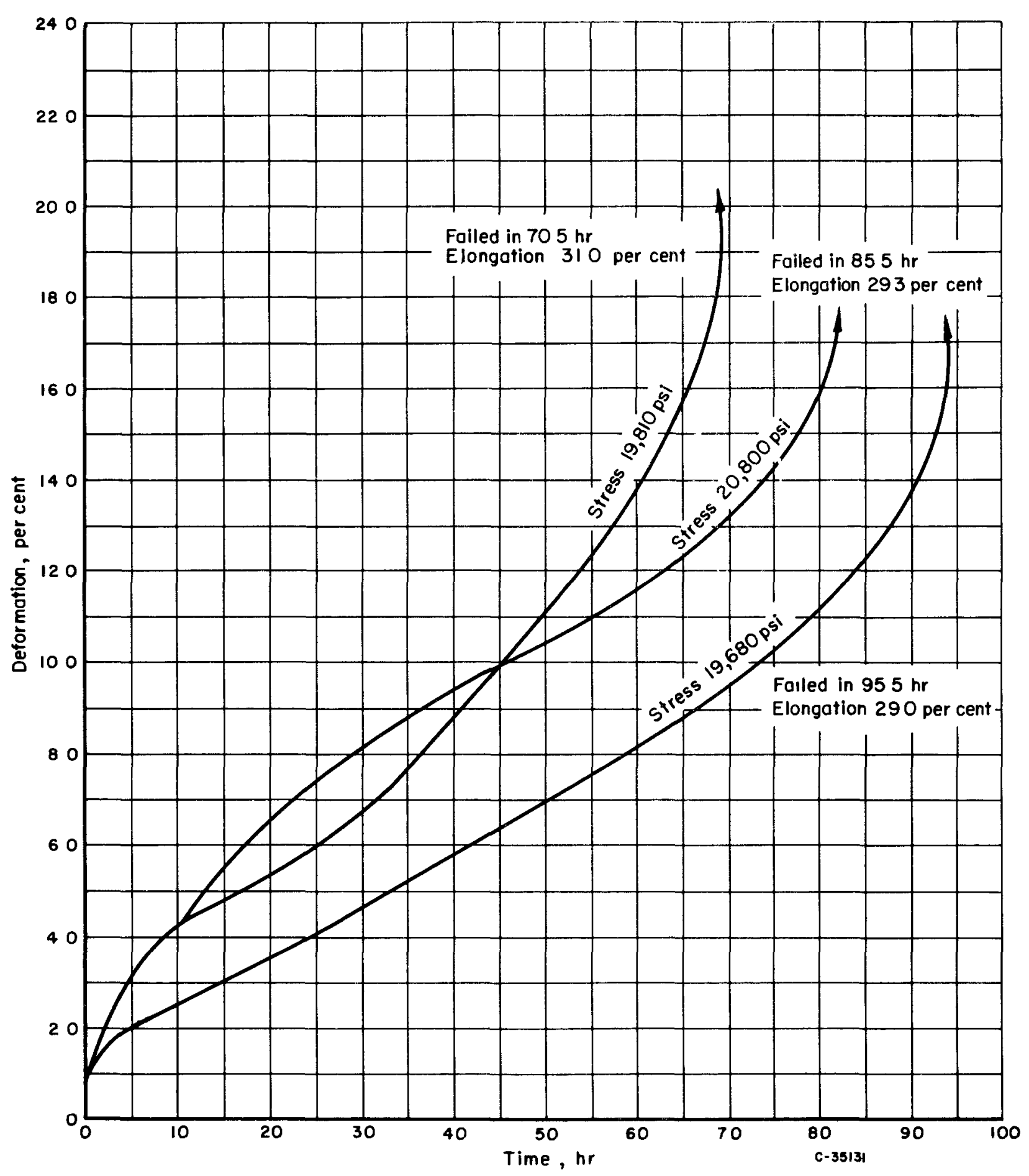

FIGURE 10. DEFORMATION-VERSUS-TIME CURVES FOR ZIRCALOY-2 TESTED IN 750 F STEAM 


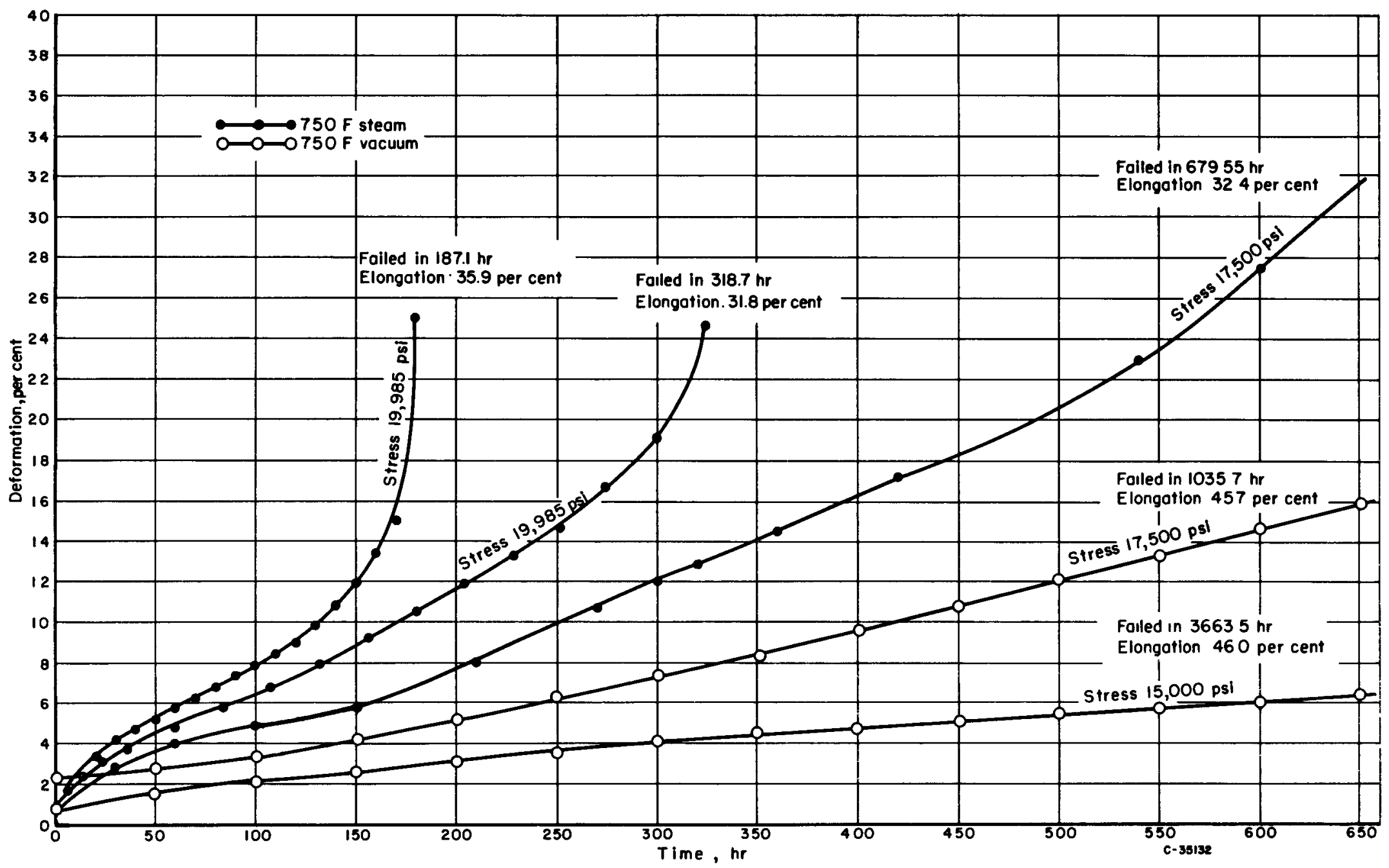

FIGURE 11. DEFORMATION-VERSUS-TIME CURVES FOR ZIRCALOY-2 IN 750 F STEAM AND VACUUM 
TABLE 1. ANNEALED ZIRCALOY -2 CREEP PROPERTIES AS TESTED AT $750 \mathrm{~F}$ IN STEAM AND IN VACUUM

\begin{tabular}{|c|c|c|c|c|c|c|}
\hline $\begin{array}{c}\text { Test } \\
\text { Environment }\end{array}$ & Specimen & $\begin{array}{c}\text { Stress, } \\
\text { psi }\end{array}$ & $\begin{array}{c}\text { Rupture, } \\
\text { hr }\end{array}$ & $\begin{array}{c}\text { Elongation, } \\
\text { per cent }\end{array}$ & $\begin{array}{l}\text { Reduction } \\
\text { of Area, } \\
\text { per cent }\end{array}$ & $\begin{array}{c}\text { Creep Rate, } \\
\text { per cent } \\
\text { per hr }\end{array}$ \\
\hline \multirow[t]{10}{*}{ Steam } & 1 & 25,480 & 0.95 & 32.6 & - & 4.0 \\
\hline & 3 & 24,475 & 5.05 & -- & 80.4 & -- \\
\hline & 4 & 22,500 & 37.55 & 31.0 & $\cdots$ & 0.28 \\
\hline & 2 & 22,100 & 9.75 & 30.4 & 81.4 & 0.95 \\
\hline & 7 & 20,800 & 85.5 & 29.3 & 73.8 & 0.1 \\
\hline & 9 & 19,680 & 95.5 & 29.0 & 83.0 & 0.12 \\
\hline & 10 & 19,810 & 70.5 & 31.0 & 83.0 & 0.1 \\
\hline & 11 & 19,985 & 318.7 & 31.8 & 68.2 & 0.032 \\
\hline & 12 & 19,985 & 187.1 & 35.9 & 83.0 & 0.053 \\
\hline & 14 & 17,500 & 679.55 & 32.4 & 81.0 & -- \\
\hline \multirow[t]{3}{*}{ Vacuum } & $1 \mathrm{~V}$ & 21,800 & 48.7 & 21.3 & -- & -- \\
\hline & $2 \mathrm{~V}$ & 17,500 & 1035.7 & 45.7 & -- & -- \\
\hline & $3 \mathrm{~V}$ & 15,000 & 3663.5 & 46.0 & -. & -- \\
\hline
\end{tabular}

TABLE 2. CORROSION DATA FOR CREEP AND CORROSION SPECIMENS IN 750 F STEAM

\begin{tabular}{|c|c|c|c|c|c|c|}
\hline \multirow[b]{2}{*}{ Specimen } & \multirow{2}{*}{$\begin{array}{c}\text { Time, } \\
\text { hr }\end{array}$} & \multicolumn{2}{|c|}{ Weight Gain, $\mathrm{g}$} & \multicolumn{3}{|c|}{$\begin{array}{c}\text { Pretest } \\
\text { Corrosion Blank } \\
\text { Dimensions, in. }\end{array}$} \\
\hline & & Creep Specimen & Corrosion Specimen & Length & Width & Thickness \\
\hline 1 & 0.95 & $0.003^{(a)}$ & $0.009^{(a)}$ & 1.994 & 0.899 & 0.061 \\
\hline 3 & 5.05 & 0.013 & 0.004 & 1.995 & 0.871 & 0.055 \\
\hline 4 & 37.55 & 0.02 & 0.013 & 2.003 & 0.878 & 0.063 \\
\hline 7 & 85.5 & 0.02 & 0.017 & 2.002 & 0.879 & 0.063 \\
\hline 9 & 95.5 & 0.017 & 0.018 & 2.002 & 0.881 & 0.064 \\
\hline 10 & 70.5 & 0.015 & 0.006 & 2.005 & 0.879 & 0.065 \\
\hline 11 & 318.7 & 0.014 & 0.021 & 2.003 & 0.875 & 0.065 \\
\hline 12 & 187.1 & 0.017 & 0.016 & 2.003 & 0.880 & 0.064 \\
\hline 14 & 679.55 & 0.023 & 0.022 & 1.963 & 0.876 & 0.061 \\
\hline
\end{tabular}

(a) Lost weight. 


\section{CONCLUSIONS}

A test unit capable of testing materials in creep at temperatures up to $750 \mathrm{~F}$ in steam and other gaseous atmospheres has been designed and constructed. Its capability to function under conditions of elevated temperatures and pressure has been demonstrated by conducting a series of successful tests.

The effect of the formation of an oxide layer on Zircaloy- 2 on the properties during creep tests is inconclusive. The following indications, suggested by the data, might not be confirmed by further tests:

(1) The total elongation at rupture is generally lower for tests conducted in steam.

(2) The time necessary to produce 2 and 5 per cent total deformation is apparently greater in a steam atmosphere.

(3) The primary stage of creep appears longer and more pronounced in tests conducted in steam.

(4) There is no apparent relation of weight-gain data for the creep and corrosion specimens with time at test.

The $750 \mathrm{~F}$ steam atmosphere did not appear to have a pronounced effect on the creep properties of Zircaloy-2. The results of this preliminary program did, however, indicate that additional studies would be necessary to determine the effect on creep properties of such parameters as oxide thickness, microcracks in the oxide, and the adherence of the oxide under thermal cycling.

\section{REFERENCES}

(1) Lustman, B., and Kerze, F. Jr., The Metallurgy of Zirconium, McGraw-Hill Book Company, New York (1955).

(2) Markowitz, M. M., "Hydrogen Redistribution in Thin Plates of Zr Under Large Thermal Gradients", WAPD-TM-104 (January 15, 1958).

(3) "Pressurized Water Reaction (PWR) Project Technical Progress Report for the Period October 24, 1958, to December 23, 1958", WAPD-MRP-77. 